\title{
LUT
}

University

\section{Entrepreneurial motivations as drivers of expert creativity}

Nisula Anna-Maija, Olander Heidi, Henttonen Kaisa

This is a Post-print

version of a publication

published by World Scientific Publishing Company

in International Journal of Innovation Management

DOI: $10.1142 / S 1363919617400059$

Copyright of the original publication: () World Scientific Publishing Company

Please cite the publication as follows:

Nisula, A.-M., Olander, H., Henttonen, K. (2017). Entrepreneurial motivations as drivers of expert creativity. International Journal of Innovation Management, vol. 21, issue 5. DOI: 10.1142/

S1363919617400059

This is a parallel published version of an original publication.

This version can differ from the original published article. 


\title{
Entrepreneurial motivations as drivers of expert creativity
}

\author{
Anna-Maija Nisula* \\ Lappeenranta University of Technology, School of Business \\ P.O. Box 20, FIN-53851 Lappeenranta, Finland \\ E-mail: anna-maija.nisula@lut.fi

\section{Heidi Olander} \\ Lappeenranta University of Technology, School of Business \\ P.O. Box 20, FIN-53851 Lappeenranta, Finland \\ E-mail: heidi.olander@lut.fi
}

\section{Kaisa Henttonen}

Lappeenranta University of Technology, School of Business P.O. Box 20, FIN-53851 Lappeenranta, Finland

E-mail: kaisa.henttonen@uef.fi

* Corresponding author

\begin{abstract}
Even if creativity is an essential part of innovative work, surprisingly little is known about the creativity of employee-experts and entrepreneurexperts. Awareness of the motivations that enhance creativity are important for any innovative company, because entrepreneurial motivations are likely to drive innovative individuals' creativity and performance. We take the entrepreneurial motivation dimensions of achievement, materialism, flexibility and power into examination. We argue that there are differences in the motivations of employeeexperts and entrepreneur-experts in relation to their creative performance. We use survey data from 423 expert respondents to analyse the relationships between these different motivations and creative performance. Our results indicate that there are both similarities and differences between the employee-experts and entrepreneur-experts in terms of their drivers of creativity. Entrepreneur creativity is driven by the motivations of materialism, achievement and power; for entrepreneurs, flexibility is not important. Meanwhile, employee-expert creativity is driven by achievement and power motivations; for this group, both flexibility and materialism are not important.
\end{abstract}

Keywords: Expert work; Experts; Motivation; Employee; Entrepreneur; Creativity; Performance; Achievement; Materialism; Flexibility; Power. 


\section{Introduction}

Around ten years ago, creativity in business was not a common topic in scholarly writing. However, creativity in addition to innovation is now a topic that needs to be taken seriously. Creativity does not only refer to people who have been traditionally considered creative such as artists but can also be attributed to other people, e.g., academic experts are required to be creative. Creativity, defined as creative performance behaviour (Montag et al., 2012), concerns an individual's activities that generate novel and even outstanding ideas and solutions for emerging problems, capture opportunities, and take risks to demonstrate originality in one's work (Tierney and Farmer, 2002; Tierney, Farmer and Graen, 1999; Amabile, 1996, 1997). Creativity, exemplified by creative contributions, is important for employees themselves, not to mention their organizations. Creativity is especially critical when the primary tasks of an individual concern innovation, research, new product development $(\mathrm{R} \& \mathrm{D})$ and design. Additionally, creative employees produce value also for organisations where creativity is not directly required (Eisenberger and Aselage, 2009).

There is wide agreement that both individual attributes and contextual aspects impact individual creativity (Oldham and Cummings, 1996; Amabile, 1996, Shalley and Gilson, 2004; Egan, 2005; Liu et al., 2016; Dul, Ceylan and Jaspers, 2011). Motivations are the most studied individual factors in relation to creativity. Intrinsic motivation refers to an individual's deep interest, enjoyment and passion in the task or broader work, while an extrinsically motivated individual is driven by external stimuli, that is, rewards, goals, reputation and recognition (Ryan and Deci, 2000). Where intrinsic motivation is identified as the key driver of individual creativity (Csikszentmihalyi, 1996; Amabile, 1988; Tierney and Farmer, 2002), there are mixed results in terms of extrinsic motivation: some extrinsic motivations may undermine intrinsic motivation (Deci and Ryan, 2002), but both types of motivation can also support each other (Thomas, 2000). Studies on creativity motivation suggest that different types of motivation beyond intrinsic motivation interact with personal and contextual factors to impact creativity (Deci and Ryan, 1985; Liu et al., 2016). Recent studies (e.g., Jayawarna et al., 2012) indicate that various combinations of motivations drive entrepreneurs' performance. All in all, there are fewer studies, if any, that examine these different motivations, specifically in relation to expert creativity.

We identified three major research gaps in current understanding. First, surprisingly little attention is paid to the factors that drive experts' and entrepreneurs' creativity (Liu et al., 2016), even though creativity is essential in knowledge work (Dul et al., 2011) and entrepreneurial processes (Chen and Yang, 2009; Mambula and Sawyer, 2004; Pretorius, Millard and Kruger, 2005; Zhou, 2008). Some scholars consider entrepreneurship to be a form of creativity, which displays creative entrepreneurial activity, that is, the generation and implementation of novel, useful ideas to profit a business (Ardichvili et al., 2003; Ward, 2004; Amabile, 1997; Dayan et al., 2013, Chen and Yang, 2009). Thus, it is likely that the same motivations drive both entrepreneurial creativity and performance. However, few studies, if any, have linked entrepreneurial motivations and entrepreneurs' creativity. Second, while previous studies have examined the impact of motivation and innovativeness on work performance in general (often in terms of intrinsic and extrinsic motivation), they have not systematically evaluated different types of motivations such as the drive for achievement, flexibility or power, which might affect an individual's creative performance. Third, the number of independent experts working as freelancers, self-employed entrepreneurs or both is increasing, and it is likely that various motivations in addition to intrinsic motivation drive these independent experts' creativity. Past research shows that 
individuals vary in their level (amount) of motivation and type of motivation (Ryan and Deci, 2000) and that motivations also drive career choice (Feldman and Bolino, 2000; Schein, 1978, 1990; Jayawarna et al., 2013). It is therefore important to shed light on the types of motivations that drive the creative performance of highly educated experts in the contemporary economy.

We rely on the assumption that highly educated experts (whether they work as employees or as entrepreneurs) are increasingly required to work with an entrepreneurial attitude in the contemporary environment; we therefore examine the effect of entrepreneurial motivations on expert creativity. For that purpose, we take entrepreneurial motivation, with the dimensions of achievement, materialism, flexibility and power (Jayawarna et al., 2011), as the starting point in our examination. We define entrepreneurexperts as those who do not earn a wage or salary but gain their income using their profession at their own risk and for themselves, whereas employee-experts, in this paper, are those who earn a wage or salary (Parker, 2004). In addition, we argue, that there could be differences in how employee-experts ${ }^{1}$ and entrepreneur-experts ${ }^{2}$ are motivated in terms of creative performance. We therefore pose the following research questions: What are the effects of the entrepreneurial motivations of achievement, materialism, flexibility and power on expert creativity? and Are there differences between employee- and entrepreneur-experts in terms of the motivation-creative performance relationship? To answer these questions, we first conducted a literature review and then formulated hypotheses before empirically testing the hypotheses with data collected from 425 expert respondents via a web-based survey.

\section{Expert motivation and creativity}

Experts are highly educated people whose work involves a large amount of knowledgeintensive aspects. The knowledge-intensive nature of expert work is grounded by autonomy, complex problem solving, knowledge creation and continuous development, which collectively result in creativity, invention and innovation. In this sense, expert work is grounded to great extent by entrepreneurial characteristics. Thus, certain kinds of aspects motivate and drive expert work. In the following section, we examine achievement, materialism, flexibility and power to explore potential relationships between these motivations and expert creativity.

\footnotetext{
1 An employee-expert works for a company or other organisation on a fixed-term contract or permanent contract and to whom labour legislation is employed where applicable.

2 An entrepreneur-expert includes may be an entrepreneur that employs other employees, selfemployment employed or working as an independent consultant or service provider independently with different partners and customers.
} 


\section{Achievement and materialism}

The motivation of achievement reflects a need for self-actualization and is grounded in intrinsic interest towards personal achievement, the work itself, responsibility, personal growth and development (Hertzberg, 1974). An individual's intrinsic interest indicates enjoyment of work that makes a significant contribution to one's creativity for its own sake (Shalley et al., 2004). As building high-level expertise demands extensive time and effort, experts tend to be self-motivated and driven by intrinsic curiosity (Amabile, 1993; Andreeva et al., 2006) and the related promise of their sense of achievement and curiosity being fulfilled. Achievement motivation refers to the willingness to take risks and generate novel ideas in order to be successful (James and Mazerolle, 2002), as well as using one's problem solving abilities, which is likely to lead to even higher levels of creative performance. Hence, achievement-oriented individuals prefer novel solutions and may even see inappropriate known solutions as opportunities to come up with something new and challenging (James and Mazerolle, 2002). Where creative solutions are often less favourable for individuals due to their higher risks (Mueller et al., 2012), achievementmotivated individuals, however, tend to see the risks of creative solutions as positive challenges (Shalley, 1995).

Materialism can be seen as similar to the well-known concept of extrinsic motivation. Whereas intrinsic motivation refers to an individual's internal desire to engage in a task for its own value, extrinsic motivation refers to a desire stemming from an outside stimulus such as tangible outcomes (Dubini, 1989), including wealth (Birley and Westhead, 1994), financial success or a good job (An et al., 2016; Ryan and Deci, 2000; Carter et al., 2003). Building on Maslow's Hierarchy of Human Needs (Maslow, 1943), Inglehart posited that while everyone seeks freedom and autonomy, the highest value is placed on the most urgent needs. This is why in socioeconomic environments with low material sustenance and physical security, people are likely to prefer materialistic values. On the other hand, if materialistic goals have been fulfilled, "postmaterialist" values such as autonomy will be focused on (Inglehart, 1990). The relationship between socioeconomic conditions and priorities in values is not, however, obvious. The "socialization" hypothesis (Inglehart, 1990) suggests that values do not change very much after an individual has reached adulthood (Rokeach, 1973).

In previous research, the relationship between experts' extrinsic motivation (materialism) and creative performance is not clear (An et al., 2016). Researchers have raised concerns over the negative effects of materialism on creative performance by minimizing the importance of intrinsic interest and creativity (Eisenberger and Aselage, 2009), yet materialism, as extrinsic motivation, may also have an improving effect when extrinsic rewards are linked to the quality of the end result (An et al., 2016; Eisenberger and Aselage, 2009, Eisenberger et al., 1999; Eisenberger and Rhoades, 2001).

Based on the context presented above, we hypothesise the following:

H1: Achievement motivation is related to experts' creativity.

H2: Materialism motivation is related to experts' creativity. 


\section{Flexibility}

The dimension of flexibility, which refers to an entrepreneur's desire to arrange one's own work, combine work and family life and control one's time and independence (Jayawarna, 2013), is grounded in Dubini's (1989) “freedom” factor and Carter et al.'s (2003) work on "independence". Carter et al. (2003, p. 14) described independence as an "individual's desire for freedom, control, and flexibility in the use of one's time". In short, flexibility as a motivation dimension could be described as an expert's motivation to conduct his/her work in the way that best suits his/her task and extra-work life.

Some studies link flexibility-related motivation to creativity. Scholars such as Shalley (1991, 1995), Oldham and Cummings (1996) and Amabile (1996) have stated that working environments that provide freedom are important for employees' creativity and their creative performance. Work environments managed by superiors who are supportive and not overly controlling - and therefore enhance experts' flexibility and independencefoster creativity (Oldham and Cummings, 1996). Leadership has been deemed less necessary in knowledge-intensive expert organisations because these experts tend to be more intrinsically than extrinsically motivated, and leadership relates more to extrinsic that intrinsic factors (Goodall and Bäker, 2015). However, recent studies on leaders' roles in organisational performance suggest that they have considerable influence in organisations such as universities, research institutes, and hospitals and that experts and professionals desire leadership by other experts and professionals with a deep understanding of the business of the organisation (Goodall and Bäker, 2015). Understanding the culture and value system of expert-employees, including their incentives and motivations, likely helps leaders create the right kinds of conditions for these employees. Such conditions, we believe, include an appreciation of flexibility as a motivating factor that will enhance the creativity of these experts.

Entrepreneur-experts, on the other hand, are self-employed and self-led (selforganised) and more or less able to determine their own work-life balance and maintain independence while still carrying the entire responsibility of a business in the absence of superiors. This refers also to freelancers and other types of independent expert workers in the modern economy. In this regard, we hypothesise the following:

\section{H3: Flexibility motivation is related to experts' creativity.}

\section{Power}

The concept of power refers to autonomy, that is, one's desire to make decisions, have the freedom to adapt his or her own approaches to work and be "one's own boss". In other words, power is one's "desire for controlling situations by being the "leader" (Jayawarna, et al., 2013, 43). In this sense, autonomy is displayed by an individual leading and organising his or her own work; these are key characteristics of any expert, as well as entrepreneurial work. Previous studies by several scholars (Bucher and Stelling, 1969; Goodall and Bäker, 2015; Robertson and Hammersley, 2000; Robertson and Swan 2003) confirm that autonomy is important for knowledge workers. People with a high need for autonomy prefer doing self-directed work, are less likely to take others' opinions and rules 
into account and like to make decisions alone (Pritchard and Karasick, 1973). When comparing employee-experts to entrepreneur-experts, business ownership provides individuals more freedom to organise their work and personal life. Baum et al. (1993) pointed out that theories on entrepreneurship demonstrate that entrepreneurship as a work role is driven by the need to be autonomous from group pressure when allocating human and capital resources.

Research on the relationship between power motivation and creativity is inconsistent. Some studies show that power is related to creativity (Galinsky et al., 2008), while others note the opposite (Kuhl and Katzen, 2008). It could be that powerful experts take more risks and are free from the influence of others and therefore end up being more creative. Without power, one might feel as if risk-taking is pointless and could therefore be more reluctant to take risks. The effect on creativity would likely be negative in this scenario. As Sligte et al. (2011) suggest, stability/instability could affect the power-creativity relationship. In an unstable situation, experts with less power could be more creative because they may be better able to see the chances of reward in the form of increased power. Powerful people, on the other hand, may show more tendency toward creativity in the presence of stability than in situations where their position is not stable and risk-taking is discouraged (Sligte et al., 2011). Based on this reasoning, it can be argued that if power motivates an expert, creativity likely increases, especially in the presence of stable conditions. We think this hypothesis could be especially true in the case of employeeexperts who may feel that they can only win by demonstrating creativity. We believe the hypothesis can also hold in the case of entrepreneur-experts, even if they may naturally hold more power and responsibility. On the other hand, entrepreneur-experts are driven towards risk-taking in any case, and therefore, we believe their power motivation is related to creativity, as well.

Literature on entrepreneurial creativity shows that entrepreneurs need to make fast, situational and creative decisions to capture opportunities and utilise scarce resources (Timmons, 1999), which requires the appropriate power to make decisions. Thus, the power to organise and make decisions displays entrepreneurs' creativity (Ardichvili et al., 2003), that is, the creative solutions generated to achieve goals. It can be argued that the desire to make decisions and lead (power motivation) affects expert creativity.

Therefore, we propose the following:

H4: Power motivation is related to experts' creativity.

\section{Methods}

\section{Data collection}

Our analysis is based on survey data from respondents who are highly-educated Finnish experts and members of the trade union Academic Engineers and Architects in Finland (TEK). In Finland, academic engineers and architects graduate from the same institutions with approximately the same scope of studies in European Credit Transfer and Accumulation System (ECTS). The dataset was collected via a web-based questionnaire in spring 2016. The sample consists of respondents from experts across different companies 
and organizations and involve also independent entrepreneurs (company information was not collected in the survey in adherence to the principles of TEK). Because each respondent is an individual member of TEK, we treat them here as individual experts regardless of their work context.

Altogether, 4940 questionnaires were sent, and we received 425 responses, representing a response rate of $8.6 \%$. The final sample consists of 423 expert respondents, as two responses were removed due to incomplete answers. Of the respondents, $55.8 \%(\mathrm{~N}$ $=236)$ were employee-experts, $24.8 \%(\mathrm{~N}=105)$ were entrepreneur-experts, and $19.5 \%(\mathrm{~N}$ $=82$ ) were classified as "other respondents" (including academic engineering students $(\mathrm{N}$ $=24)$, unemployed experts $(\mathrm{N}=26)$, retired experts $(\mathrm{N}=27)$ and experts who are stay-athome parents $(\mathrm{N}=5)$. Of the respondents, $26.7 \%(\mathrm{~N}=112)$ were female, and $73.3 \%(\mathrm{~N}=$ $310)$ were male. The age distribution of the respondents was as follows: $13.2 \%(\mathrm{~N}=56)$ were under 29 years old, $20.3 \%(\mathrm{~N}=86)$ were between 30 and $39,26.2 \%(\mathrm{~N}=111)$ were between 40 and 49, 21.3\% $(\mathrm{N}=90)$ were between 50 and 59 and $18.9 \%(\mathrm{~N}=80)$ were over 60. In terms of educational attainment, the distribution of the respondents was as follows: $2.8 \%(\mathrm{~N}=12)$ were students, $3.1 \%(\mathrm{~N}=13)$ had a bachelor's as their highest degree, $78.5 \%(\mathrm{~N}=332)$ had a master's as their highest degree, $15.1 \%(\mathrm{~N}=64)$ had doctorates and $0.5 \%(\mathrm{~N}=2)$ had other levels of educational attainment.

\section{Measures}

The measured constructs were multi-item constructs, and they were captured by a sevenpoint Likert scale $(1=$ strongly disagree, $7=$ strongly agree $)$. The constructs were adopted from existing scales in the extant literature and are presented in Appendix I.

Individual creativity was measured with six items adapted from a study by Tierney, Farmer and Graen (1999). Self-reporting is the most relevant method of measurement in this study because the individuals themselves are in the best position to evaluate their creative behaviour (Shalley et. al., 2009; Conway and Lance, 2010). However, to test the common method bias likely present in self-reported measures, we used Harman's onefactor test (Podsakoff et al., 2003) and found that the largest factor accounted for 34.59\%. This indicated that common method bias was not a concern.

Scales for the motivations of achievement, flexibility, materialism and power were adapted from the study by Jayawarna et al. (2011). Each motivation variable consisted of three items. 


\section{Analysis and findings}

A proposed theoretical model concerning the connections between the motivations (achievement, flexibility, materialism and power) of expert creativity was empirically tested with Partial Least Square (PLS) SEM analysis. The PLS SEM analysis was used to estimate the hypothesised causal relationships between the variables.

\section{Measurement model}

Composite reliability values of the constructs varied between $0.75-0.91$, all of which are above the suggested value of 0.70 (Nunnally and Bernstein, 1994; Hair et al., 2011) and demonstrate high levels of internal consistency reliability (Table 1).

Construct reliability (CR) and convergent validity of the constructs represent internal consistency. The construct reliability of the all the constructs showed a high reliability (value above the threshold 0.70). For convergent validity, first, the average variance extracted (AVE) value of each construct should exceed the cut-off (0.50); the AVE values of the constructs varied between $0.51-0.73$ (Table 1 ). Second, the outer loadings of each item should exceed the cut-off (0.60). We accepted one individual indicator with loading of 0.56 on the materialism scale because the scale was equal with the Jayawarna et al. (2013) scale. This is in line with Barclay et al. (1995) and Hair et al. (2011) who suggest that lower single indicator loadings could be acceptable if composite reliability is high enough (in this case, composite reliability of the materialism construct is 0.75 ).

Table 1 Construct statistics

\begin{tabular}{lccccc}
\hline Construct & Mean & SD & AVE & $\begin{array}{c}\text { Composite } \\
\text { reliability }\end{array}$ & Item loadings \\
\hline Creativity & 5.0307 & 0.93473 & 0.63 & 0.91 & $0.74-0.84$ \\
Materialism & 5.3117 & 0.88214 & 0.51 & 0.75 & $0.56-0.91$ \\
Achievement & 5.1245 & 0.90737 & 0.54 & 0.78 & $0.69-0.79$ \\
Flexibility & 5.7037 & 0.81847 & 0.60 & 0.81 & $0.64-0.90$ \\
Power & 5.2931 & 1.01786 & 0.73 & 0.89 & $0.84-0.87$ \\
\hline
\end{tabular}

To assess discriminant validity, we compared the Fornell-Larcker criterion (Fornell and Larcker, 1981) with cross loadings by comparing the square root of the AVE (on the diagonal in Table 2) with the correlations between the latent constructs. All the square root values of AVE were higher than the correlations between latent constructs, and the discriminant validity is confirmed (Hair et al., 2011). Furthermore, all the items loaded highest on the proposed construct, which indicates discriminant validity (Hair et al., 2011). 
Table 2 Correlation matrix

\begin{tabular}{lcccccccc}
\hline Construct & 1 & 2 & 3 & 4 & 5 & 6 & 7 & 8 \\
\hline 1. Creativity & $\mathbf{0 . 7 9}$ & & & & & & & \\
2. Materialism & $0.32^{* *}$ & $\mathbf{0 . 7 1}$ & & & & & & \\
3. Achievement & $0.50^{* *}$ & $0.38^{* *}$ & $\mathbf{0 . 7 3}$ & & & & & \\
4. Flexibility & $0.22^{* *}$ & $0.42^{* *}$ & $0.33^{* *}$ & $\mathbf{0 . 7 7}$ & & & & \\
5. Power & $0.46^{* *}$ & $0.53^{* *}$ & $0.52^{* *}$ & $0.54^{* *}$ & $\mathbf{0 . 8 5}$ & & & \\
6. Education & $0.21^{* *}$ & $0.12^{*}$ & 0.08 & $0.21^{* *}$ & $0.12^{*}$ & $\mathbf{1 . 0 0}$ & & \\
7. Gender & $0.16^{* *}$ & -0.03 & 0.04 & -0.06 & -0.02 & $-0.13^{* *}$ & $\mathbf{1 . 0 0}$ & \\
8. Age & $0.15^{* *}$ & 0.03 & $0.20^{* *}$ & $0.13^{* *}$ & $0.13^{* *}$ & $0.29 * *$ & $0.19^{* *}$ & $\mathbf{1 . 0 0}$ \\
\hline
\end{tabular}

Note1: **) correlation is significant at the 0.01 level (2-tailed), *) correlation is significant at the 0.05 level (2-tailed)

Note2: The square root of the construct's AVE value is presented on the diagonal (in bold).

To assess the model's predictive accuracy $\left(\mathrm{R}^{2}\right)$ and the significance of the structural paths, we conducted the PLS Bootstrapping procedure. The results of that procedure are discussed in the following section.

\section{Results}

When testing the hypothesised model with the full dataset $(\mathrm{N}=423)$, the model was able to explain $36.6 \%$ of the variance in expert creativity. The results show (Table 3 ) that the motivation constructs of materialism (extrinsic motivation) $(\mathrm{H} 1: \beta=0.014 ; \mathrm{p}<0.025)$, achievement (intrinsic motivation) $(\mathrm{H} 2: \beta=0.347 ; \mathrm{p}<0.005)$ and power $(\mathrm{H} 4: \beta=0.250$; $\mathrm{p}<0.005)$ all had a positive and significant impact on expert creativity. However, flexibility (H3: $\beta=-0.097 ; \mathrm{p}<0.05)$ had a negative and significant impact on expert creativity. Regarding the control variables, education $(\beta=0.187, p<0.005)$ and gender $(\beta$ $=0.184, \mathrm{p}<0.005)$ had a positive and strong impact on expert creativity, whereas age $(\beta=$ -0.019 ) was non-significant.

After analysing the data as one collective sample, we compared the results of employees-experts $(\mathrm{N}=236)$ with entrepreneur-experts $(\mathrm{N}=105)$ in order to gain more insights on possible differences between the motivations of highly-educated experts whose career choices differed in terms of employment vs. entrepreneurship.

While testing the hypothesised model with the entrepreneur dataset $(\mathrm{N}=105)$ the model was able to explain $37.9 \%$ of the variance in entrepreneur-expert creativity. The results (Table 3 ) show that materialism $(\mathrm{H} 1: \beta=0.200 ; \mathrm{p}<0.01)$, achievement $(\mathrm{H} 2: \beta=$ $0.262 ; \mathrm{p}<0.005)$ and power $(\mathrm{H} 4: \beta=0.154 ; \mathrm{p}<0.05)$ all had a positive and significant impact on entrepreneur creativity. In contrast, the impact of flexibility (H3: $\beta=0.038)$ was non-significant. Of the control variables, education $(\beta=0.247$; $<<0.005)$ and gender $(\beta=$ $0.266 ; p<0.005)$ were significant, whereas age was non-significant $(\beta=-0.086)$. 
Table 3 Testing the model

\begin{tabular}{|c|c|c|c|c|}
\hline \multirow{2}{*}{$\begin{array}{l}\text { All experts }\left(\mathbf{N}=\mathbf{4 2 3} ; \mathbf{R}^{2}=\mathbf{0 . 3 6 6}\right) \\
\text { H1 Materialism -> Creativity }\end{array}$} & \multirow{2}{*}{$\frac{\text { Path coefficient }}{0.1042}$} & \multicolumn{2}{|c|}{ T Statistics } & \multirow{2}{*}{$\frac{\text { Sig. }}{0.025}$} \\
\hline & & 2.08 & $* *$ & \\
\hline H2 Achievement $->$ Creativity & 0.3472 & 7.07 & $* * *$ & 0.005 \\
\hline H3 Flexibility $>$ Creativity & -0.0965 & 1.86 & * & 0.05 \\
\hline H4 Power -> Creativity & 0.2495 & 4.13 & $* * *$ & 0.005 \\
\hline Education -> Creativity & 0.187 & 4.82 & $* *$ & 0.005 \\
\hline Gender -> Creativity & 0.1837 & 4.61 & $* *$ & 0.005 \\
\hline Age $->$ Creativity & -0.019 & 0.45 & & \\
\hline Entrepreneur-experts $\left(\mathrm{N}=105 ; \mathbf{R}^{2}=\mathbf{0 . 3 7 9}\right)$ & Path coefficient & T Sta & & \\
\hline H1 Materialism -> Creativity & 0.1995 & 2.37 & $* *$ & 0.01 \\
\hline H2 Achievement -> Creativity & 0.2617 & 2.83 & $* * *$ & 0.005 \\
\hline H3 Flexibility $>$ Creativity & 0.0375 & 0.41 & & \\
\hline H4 Power -> Creativity & 0.1542 & 1.75 & * & 0.05 \\
\hline Education $->$ Creativity & 0.2467 & 3.10 & $* * *$ & 0.005 \\
\hline Gender $->$ Creativity & 0.2663 & 3.31 & $* * *$ & 0.005 \\
\hline Age -> Creativity & -0.0963 & 1.07 & & \\
\hline Employee-experts $\left(N=236 ; R^{2}=0.376\right)$ & Path coefficient & T Sta & & \\
\hline H1 Materialism -> Creativity & 0.0992 & 1.34 & & \\
\hline H2 Achievement -> Creativity & 0.3969 & 6.07 & $* * *$ & 0.005 \\
\hline H3 Flexibility $>>$ Creativity & -0.1166 & 1.55 & & \\
\hline H4 Power -> Creativity & 0.2286 & 2.40 & $* *$ & 0.025 \\
\hline Education $->$ Creativity & 0.2018 & 3.42 & $* * *$ & 0.005 \\
\hline Gender -> Creativity & 0.1684 & 3.07 & $* * *$ & 0.005 \\
\hline Age $->$ Creativity & 0.0081 & 0.16 & & \\
\hline
\end{tabular}

Finally, we tested the model with the employee dataset $(\mathrm{N}=236)$. The model was able to explain $37.6 \%$ of the variance in employee-expert creativity (Table 3). More specifically, achievement $(H 2: \beta=0.397 ; p<0.005)$ and power $(H 4: \beta=0.229 ; p<0.025)$ had a positive and significant impact on employee-expert creativity. In contrast, the motivations of materialism (H1: $\beta=0.099 ; \mathrm{p}<0.1)$ and flexibility $(\mathrm{H} 3: \beta=-0.117 ; \mathrm{p}<0.1)$ were nonsignificant. Of the control variables, education $(\beta=0.202 ; \mathrm{p}<0.005)$ and gender $(\beta=$ $0.168 ; p<0.005)$ were significant, whereas age was non-significant $(\beta=-0.008)$. 


\section{Discussion and contribution}

\section{The effect of motivations on expert creativity in general}

In this study, we examined the impact of four dimensions of entrepreneurial motivations on creativity: achievement, materialism, flexibility and power. Additionally, we examined the motivation-creativity relationship amongst two groups: employee-experts and entrepreneur-experts. First, we found that the motivations of materialism, achievement, and power are important and contribute to expert creativity in our collective sample. These findings align with previous studies showing that both intrinsic (achievement) and extrinsic (materialism) motivations drive expert creativity. Although intrinsic motivation is seen as a key driver of individual creativity (Csikszentmihalyi, 1998; Amabile, 1988; Tierney and Farmer, 2002), extrinsic motivation is also important for individual creativity (Deci and Ryan, 1985; Liu et al., 2016). Furthermore, our results add to current understanding by showing that entrepreneurial motivations are related to expert creativity, a field still relatively under researched. Additionally, we found that the motivation of flexibility is important for experts in general, as well, but it contributes negatively to expert creativity. This was somewhat surprising as flexibility refers to one's interest in organising one's own work, that is, one's desire to have freedom and autonomy to make decisions regarding one's own work. One explanation for this negative relationship could be that, given the general sample included students, retired experts and unemployed experts, too much freedom directs a relatively large amount of time and focus on organising time spent away from the creative work. This could also hint that inexperience (in students, for example) determines a need for control or being in a situation where one might otherwise call for incentives and the organising of one's own time (amongst retired experts and unemployed experts, for example). Too much time and flexibility can also become a "block to creativity". There might also be individual differences between drivers of creativity, and it might be that highly intrinsically motivated experts are less willing to spend time organising and prefer to use their time on "what really matters".

\section{Similarities and differences between entrepreneur-experts and employee-experts in terms of their motivations}

A closer look at employee-experts and entrepreneur-experts revealed both similarities and differences in terms of their creativity drivers. Entrepreneur-expert creativity was driven by the motivations of materialism, achievement and power, whereas flexibility was not important. In contrast, employee-expert creativity was driven by achievement and power motivations, whereas flexibility and materialism were not important.

All in all, the motivations of achievement and power were common for both groups. However, the impact of achievement motivation on creativity was much stronger among employee-experts compared to the entrepreneur-experts. In addition, the expert groups differed in terms of materialism motivation, which had an impact on entrepreneur-expert creativity but not on employee-expert creativity. This finding may also explain the difference in achievement motivation, namely highly intrinsically motivated employeeexperts might be less driven by materialism, whereas materialism (extrinsic) motivation may be highly important for entrepreneur-expert creativity because this creative activity could be the only source of household income and could therefore be a necessity, in a sense. 
Consequently, this finding refers to past research, namely the scholarly discussion on intrinsic and extrinsic motivations. Our study adds to current understanding by showing that both extrinsic and intrinsic motivations are important and contribute to entrepreneurexpert creativity.

The finding that the motivation of power was important for both expert groups' creativity was in line with previous studies (Bucher and Stelling, 1969; Goodall and Bäker, 2015; Robertson and Hammersley, 2000; Robertson and Swan, 2003). This motivation seemed to be more important for employee-experts than for entrepreneur-experts, which implies that experts employed by organisations may feel their situation to be stable enough to allow for the risk taking required in creative activities (Sligte et al., 2011), whereas entrepreneur-experts could be less encouraged to take major risks. However, as stated above, entrepreneurship always involves risk-taking and require decision-making power (Ardichvili et al., 2003); this can aid in our understanding of the positive impact of the motivation of power in both groups of experts.

\section{Contribution}

The outcomes of this study show that various motivations contribute to expert creativity. While previous studies on creativity motivation have shown that different types of motivations interact with personal and contextual factors to impact creativity (Deci and Ryan, 1985; Liu et al., 2016) and that they can also support each other (Thomas, 2000), we demonstrate that various entrepreneurial motivations contribute to expert creativity.

In the contemporary work environment, organisational aspects are becoming blurred and are even disappearing as an increasing number of experts are self-employed or selforganised in organisations. Consequently, "the greatest contribution to creativity may be expected from people who have reached the self-actualization stage (and their lower) needs are already met" (Maslow, 1954; Brennan and Dooley, 2005). However, there is a need for future studies that identify the motivations that drive experts and analyse the interactions and mechanisms through which these motivations impact employee-/entrepreneur-expert creativity.

Our study contributes to understanding of expert motivation by proposing a dynamic relationship between motivation types and the creative performance of individuals. The effect of entrepreneur motivation on creativity has thus far not been sufficiently examined, and our research provides new insights on this relationship by examining highly educated experts in technology and by comparing entrepreneurs with those employed by companies in terms of their motivation-creativity relationships. We also add to the growing discussion on individual-level issues in innovation management, where research has started to pay more and more attention only rather recently (Frishammar et al., 2015; Hannah and Robertson, 2015; Ritala et al., 2015).

The present study makes two theoretical contributions. First, as far as we know, this is the first study that builds a link between entrepreneurial motivations and creativity. Previous studies on individual creativity have focussed on individual intrinsic and extrinsic motivations (Deci and Ryan, 1985; Amabile, 1996; Liu et al., 2016), showing that creative individuals (including experts) are intrinsically motivated (Csikszentmihalyi, 1998, Amabile, 1988; Tierney and Farmer, 2002). In line with this, studies on entrepreneurial creativity have used a similar set of motivations (e.g., Amabile, 1997). We contribute to the identified research gap on entrepreneurial creativity (Liu et al., 2016) by proposing a novel research design and presenting empirical evidence that entrepreneurial motivations 
of materialism, achievement and power are important and contribute to entrepreneurs' creativity. Second, our results add to the current understanding of expert (knowledge worker) creativity (e.g., Liu et al., 2016) by showing that the entrepreneurial motivations of achievement and power also drive the creative performance of employee-experts. Thus, there are both similarities and differences in terms of the motivations of knowledgeintensive expert work and entrepreneurship. The major difference is that materialism is not an important motivation for employee-expert creativity, but it is important for entrepreneur-expert creativity.

A practical implication of the outcomes of this study is that organisations aiming to utilise the creativity of highly educated experts, either internal experts or external selfemployed experts, need to pay attention to the aspects that motivate these experts to demonstrate their creativity. Stimulating and challenging work motivates experts to achieve and put effort into reaching solutions that are not necessarily the most obvious ones. As companies in knowledge-intensive industries, and especially in the field of technology, are highly dependent on their employees' creativity and ability to innovate, it is important for managers to know how certain motivations affect experts' creative performance. From an innovation management point of view, identifying which motivational factors benefit an individual's creative performance should be of benefit, as this information can help management to enhance creativity, as well as prepare for different kinds of employee-related innovation risks, for example, by adjusting an HRM system to support the motivation of employees or entrepreneurs, as contributing external experts.

Our study has certain limitations. First, our focus was on the entrepreneurial motivations of achievement, materialism, power and flexibility, and our study did not consider nor test the specific concept of intrinsic motivation, identified as a key driver of individual creativity, although achievement motivation is similar to this concept (Csikszentmihalyi, 1996, Amabile, 1988; Tierney and Farmer, 2002). In future studies, intrinsic motivation should be tested in parallel to entrepreneurial motivations in the research design. Another limitation of this study is that we studied the direct impact of entrepreneurial motivation on expert creativity, even though previous studies have shown mixed results regarding the effects of intrinsic and extrinsic motivations (Deci and Ryan, 2002; Thomas, 2000). Thus, future studies should examine the mediating and moderating relations between motivations on expert creativity. This was noted also by Liu et al. (2016). Furthermore, our study focussed on motivations and ignored the possible effects of personal and contextual factors that may interact with motivations (Deci and Ryan, 1985; Liu et al., 2016). Other issues that could affect the findings regarding materialism motivation are household income and duration of entrepreneurship, which could be controlled in further studies. For example, students might be more motivated by materialism due to their limited income while completing their studies. Also, entrepreneurs earlier in their careers may be more motivated by materialism. In our study, we did not pay attention to skills and abilities, which most likely play mediating or moderating roles in the motivation-creativity relationship. Future studies should also consider these interactions in their research design. Additionally, there might be differences between the characteristics, motivation and behaviour of engineers and architects, who were analysed collectively in this study. These differences should be considered in future studies. Although the education of engineers and architects differs to some extent, our interest was on all members of the union. Moreover, we did not control for the content of the union members' current jobs, and it is very likely that these experts (architects and engineers) work in a wide range of fields and positions, even those that might be atypical for their educational background. 


\section{References}

Amabile, T.M. (1985). Motivation and creativity: Effects of motivational orientation on creative writers. Journal of Personality and Social Psychology, 48, 393-399.

Amabile, T.M (1993). Motivational synergy: toward new conceptualizations of intrinsic and extrinsic motivation in the workplace. Human Resource Management 3(3): $185-201$

Amabile, T. M. (1996). Creativity in context: Update to" the social psychology of creativity.", Westview press.

Amabile, T. M. (1997). Entrepreneurial creativity through motivational synergy. The Journal of Creative Behavior, 31(1), 18-26.

An, D., Song, Y., and Carr, M. (2016). A comparison of two models of creativity: Divergent thinking and creative expert performance Personality and Individual Differences 90, 78-84.

Ardichvili, A., Cardozo, R. and Ray, S. (2003), "A theory of entrepreneurial opportunity identification and development", Journal of Business Venturing, Vol. 18 No. 1, pp. 105-23.

Bucher R. and Stelling, J. (1969). Characteristics of professional organizations. Journal of Health Social Behavior, 10, 3-15.

Baum, J. Olian, J.D, Erez, M, Schnell, E.R., Smith, K.G., Sims, H.P., Scully, J.S. \& Smith, K.A. (1993) Nationality and work role interactions: a cultural contrast of Israeli and US entrepreneurs versus managers' needs, Journal of Business Venturing, Vol. 8, pp. 499512.

Birley, S., \& Westhead, P. (1994). A taxonomy of business start-up reasons and their impact on firm growth and size. Journal of business venturing, 9(1), 7-31.

Brennan, A., \& Dooley, L. (2005). Networked creativity: a structured management framework for stimulating innovation. Technovation, 25(12), 1388-1399.

Podsakoff, P. M., MacKenzie, S. B., Lee, J. Y., \& Podsakoff, N. P. (2003). Common method biases in behavioral research: a critical review of the literature and recommended remedies. Journal of applied psychology, 88(5), 879.

Carter, N. M., Gartner, W. B., Shaver, K. G., \& Gatewood, E. J. (2003). The career reasons of nascent entrepreneurs. Journal of Business Venturing, 18(1), 13-39.

Chen, M. H., \& Yang, Y. J. (2009). Typology and performance of new ventures in Taiwan: A model based on opportunity recognition and entrepreneurial creativity. International Journal of Entrepreneurial Behavior \& Research, 15(5), 398-414.

Conway, J. M., \& Lance, C. E. (2010). What reviewers should expect from authors regarding common method bias in organizational research. Journal of Business and Psychology, 25(3), 325-334.

Csikszentmihalyi, M. (1996). Flow and the psychology of discovery and invention. New York: Harper Collins.

Dayan, M., Zacca, R., \& Di Benedetto, A. (2013). An exploratory study of entrepreneurial creativity: its antecedents and mediators in the context of UAE firms. Creativity and Innovation Management, 22(3), 223-240.

Deci, E. L., \& Ryan, R. M. (2002). Handbook of self-determination research. University Rochester Press.

Dubini, P. (1989). The influence of motivations and environment on business start-ups: Some hints for public policies. Journal of business venturing, 4(1), 11-26. 
Dul, J., Ceylan, C., \& Jaspers, F. (2011). Knowledge workers' creativity and the role of the physical work environment. Human Resource Management, 50(6), 715-734.

Egan 2005: "Factors Influencing Individual Creativity in the Workplace: An Examination of Quantitative Empirical Research", Advances in Developing Human Resources

Eisenberger, R., \& Aselage, J. (2009). Incremental effects of reward on experienced performance pressure: Positive outcomes for intrinsic interest and creativity. Journal of Organizational Behavior, 30, 95-117.

Eisenberger, R., \& Rhoades, L. (2001). Incremental effects of reward on creativity. Journal of Personality and Social Psychology, 81, 728-741.

Eisenberger, R., Pierce, W.D., \& Cameron, J. (1999). Effects of reward on intrinsic motivation-negative, neutral, and positive: Comment on Deci, Koestner, and Ryan (1999). Psychological Bulletin, 125, 677-691.

Feldman, D. C., \& Bolino, M. C. (2000). Career patterns of the self-employed: Career motivations and career outcomes. Journal of Small Business Management, 38(3), 53.

Fiske, S. T. (1993). Social cognition and social perception. Annual Review of Psychology, 44, 155-194.

Frishammar, J., Ericsson, K., \& Patel, P. C. (2015). The dark side of knowledge transfer: exploring knowledge leakage in joint R\&D projects. Technovation, 41, 75-88.

Fornell, C., \& Larcker, D. F. (1981). Evaluating structural equation models with unobservable variables and measurement error. Journal of marketing research, 39-50.

Galinsky, A. D., Magee, J. C., Gruenfeld, D. H., Whitson, J. A., and Liljenquist, K. A. (2008). Power reduces the press of the situation: Implications for creativity, conformity, and dissonance. Journal of Personality and Social Psychology, 95, 1450-1466.

Goodall, A.H. and Bäker, A. (2015) A theory exploring how expert leaders influence performance in knowledge-intensive organizations, in: Incentives and Performance, Eds. Welpe, I.M., Wollersheim, J., Ringelhan, S. and Osterloh, M. Springer International Publishing, pp. 49-67.

Hannah DR \& Robertson K. (2015). Why and how do employees break and bend confidential information protection rules? Journal of Management Studies, 52, 381-413.

Hair, J. F., Ringle, C. M., \& Sarstedt, M. (2011). PLS-SEM: Indeed a silver bullet. Journal of Marketing theory and Practice, 19(2), 139-152.

Inglehart, R. (1990), Culture Shift in Advanced Industrial Society, Princeton University Press, Princeton, NJ.

James, L. R., \& Mazerolle, M. D. (2002). Personality in work organizations. Thousand Oaks, CA: Sage.

Jayawarna, D., Rouse, J. and Kitching, J. (2011) Entrepreneur motivations and life course, International Small Business Journal, 31(1), 34-56.

Kuhl, J., \& Kazen, M. (2008). Motivation, affect, and hemispheric asymmetry: Power versus affiliation. Journal of Personality and Social Psychology, 95, 456-469.

Liu, D., Jiang, K., Shalley, C. E., \& Keem, S. (2013, January). The Underlying Motivational Mechanisms for Employee Creativity: A Meta-Analytic Examination. In Academy of Management Proceedings (Vol. 2013, No. 1, p. 16183). Academy of Management.

Mambula, C., \& Sawyer, F. E. (2004). Acts of entrepreneurial creativity for business growth and survival in a constrained economy: Case study of a small manufacturing firm (SMF). International Journal of Social Economics, 31(1/2), 30-55. 
Maslow, A. (1943). A theory of human motivation. Psychological Review 50(4): 370396.

Montag, T., Maertz, C. P., \& Baer, M. (2012). A critical analysis of the workplace creativity criterion space. Journal of Management, 38(4), 1362-1386.

Mueller, J. S., Melwani, S., \& Goncalo, J. A. (2012). The bias against creativity: Why people desire but reject creative ideas. Psychological Science, 23, 13-17.

Nunnally, J. C., \& Bernstein, I. H. (1994). The assessment of reliability. Psychometric theory, 3(1), 248-292.

Oldham, G.R. and Cummings, A. (1996). Employee creativity: personal and contextual factors at work. Academy of Management Journal, 39:607-634.

Pretorius, M., Millard, S. M., \& Kruger, M. E. (2005). Creativity, innovation and implementation: Management experience, venture size, life cycle stage, race and gender as moderators.

Pritchard, R. and Karasick, B., (1973). The effects of organizational climate on managerial job performance and satisfaction", Organizational Behaviour and Human Performance, Vol. 9, pp. 126-46.

Ritala, P., Olander, H., Michailova, S. and Husted, K. (2015) Knowledge sharing, knowledge leaking and relative innovation performance: An empirical study, Technovation, 35, 22-31.

Rokeach, M. (1973). The Nature of Human Values, Free Press, New York, NY.

Robertson M, Hammersley G.O.M. (2000). Knowledge management practices within a knowledge intensive firm: the significance of the people management dimension. Journal of European Industrial Training 24(2/3/4): 241-253.

Robertson, M. and Swan, J. (2003). 'Control-what control?' Culture and ambiguity within a knowledge intensive firm. Journal of Management Studies, 40(4):831-858.

Ryan, R.M., \& Deci, E.L. (2000). Intrinsic and extrinsic motivations: Classic definitions and new directions. Contemporary Educational Psychology, 25, 54-67.

Shalley, C.E. (1991). Effects of productivity goals, creativity goals, and personal discretion on individual creativity, Journal of Applied Psychology, 76:179-185.

Shalley, C.E. (1995). Effects of coaction, expected evaluation, and goal setting on creativity and productivity. Academy of Management Journal 38:483-503.

Shalley, C. E., \& Gilson, L. L. (2004). What leaders need to know: A review of social and contextual factors that can foster or hinder creativity. The Leadership Quarterly, 15(1), 33-53.

Shalley, C. E., Gilson, L. L., \& Blum, T. C. (2009). Interactive effects of growth need strength, work context, and job complexity on self-reported creative performance. Academy of Management Journal, 52(3), 489-505.

Schein. E. H. (1978). Career dynamics: Matching individual and organizational needs. Reading, MA: Addison-Wesley.'

Parker, S.C. (2004). The economics of entrepreneurship and self-employment, University Press, Cambridge, UK.

Ryan, R. M., \& Deci, E. L. (2000). Intrinsic and extrinsic motivations: Classic definitions and new directions. Contemporary educational psychology, 25(1), 54-67.

Sligte, D, J., de Dreu, C.K.W. and Nijstad, B.A. (2011). Power, stability of power, and creativity, Journal of Experimental Social Psychology, 47, 891-897. 
Tierney, P., \& Farmer, S. M. (2002). Creative self-efficacy: Its potential antecedents and relationship to creative performance. Academy of Management journal, 45(6), 11371148.

Tierney, P., Farmer, S. M., \& Graen, G. B. (1999). An examination of leadership and employee creativity: The relevance of traits and relationships. Personnel psychology, 52(3), 591-620.

Thomas, K. W. (2000). Intrinsic motivation at work: Building energy \& commitment. Berrett-Koehler Publishers.

Ward, T.B. (2004), Cognition, creativity, and entrepreneurship, Journal of Business Venturing, Vol. 19 No. 2, pp. 173-88. 